\title{
ANALISIS IMPLEMENTASI PENYALURAN DANA ZAKAT DAN INFAK DI BADAN AMIL ZAKAT DAERAH (BAZDA) KOTA GORONTALO
}

\author{
Ivan Rahmat Santoso \\ Dosen Fakultas Ekonomi Universitas Negeri Gorontalo \\ ivanrahmatsantoso@gmail.com
}

Received: 29 Februari 2019; Revised: 12 April 2019; Accepted: 15 April 2019

\begin{abstract}
ABSTRAK
Penyaluran zakat dan infak yang berasal dari umat Islam harus sedini mungkin disalurkan secara efektif sebagai suatu sisi ikhtiar pemberdayaan ekonomi umat, ini karena dana zakat dan infak merupakan modal dalam upaya peningkatan perekonomian dan kesejahteraan umat, di mana dalam ini penyaluran zakat dan infak membutuhkan suatu pedoman dalam penyalurannya agar dana zakat dan infak dapat terealisasi dengan baik. Penelitian ini bertujuan untuk mengetahui bagaimana kesesuaian penyaluran zakat di Badan Amil Zakat Daerah (BAZDA) Kota Gorontalo dengan Pedoman Pengelolaan Zakat Tahun 2004. Analisis yang digunakan dalam penelitian ini adalah analisis deskriptif yaitu analisis yang dilakukan melalui studi lapangan dengan pengumpulan data mengenai penyaluran dana zakat dan infak. Hasil penelitian ini menunjukkan bahwa impementasi penyaluran dana zakat dan infak di Badan Amil Zakat Daerah Kota Gorontalo sesuai dengan pedoman pengelolaan zakat Departemen Agama Republik Indonesia Tahun 2004, dimana dalam pendayagunaan zakat secara prinsip dana tersebut diberikan kepada delapan asnaf, manfaat zakat dan infak dapat diterima dan dirasakan manfaatnya serta sesuai dengan keperluan mustahiq (konsumtif dan produktif), dan pendayagunaan zakat tersebut ditujukan untuk program jangka panjang untuk perbaikan kesejahteraan dan meningkatkan status mustahiq menjadi muzakki.
\end{abstract}

Kata kunci: zakat, infak, Muzakki dan Mustahiq

\section{PENDAHULUAN}

Hubungan kaya-miskin dalam syari'at Islam dilandaskan pada aksioma: di dalam harta orang kaya terdapat hak peminta-minta dan yang berkekurangan (QS. Al-Dzariyat:19), peminta-minta adalah mereka yang terpesona non gratakan dalam struktur ekonomi, mereka bukanlah makhluk yang lemah dan tidak mempunyai daya kodrati untuk berusaha, tetapi kemauan mereka tidak memungkinkannya untuk andil besar dalam laju perekonomian, kenyataan ini diperparah lagi dengan sistem ekonomi yang tidak seimbang, laju perekonomian yang lebih didominasi masyarakat perkotaan berimplikasi kepada rendahnya perkembangan perekonomian di desa, dan pada akhirnya lahirlah para peminta-minta yang membanjiri kota besar.

Penyebab kemiskinan, paling tidak berasal dari dari dua hal atau bahkan kedua-duanya dimana Pertama, kemiskinan itu sebagai akibat dari kemalasan (kemiskinan kultural) dan ketidakmampuan seseorang untuk bekerja mencari nafkah untuk memenuhi kebutuhan hidupnya. Kedua, kemiskinan struktural, yaitu kemiskinan sebagai akibat dari pola kehidupan yang tidak adil dan penuh kezaliman, harta kekayaan milik bersama dikuasai oleh sekolompok orang untuk kepentinganya sendiri.

Kemiskinan struktural inilah penyebab kemiskinan yang paling menonjol di banyak tempat dan Negara, Susan George dalam How The Other All Dies: The Real Reasonfor World Hunger, 


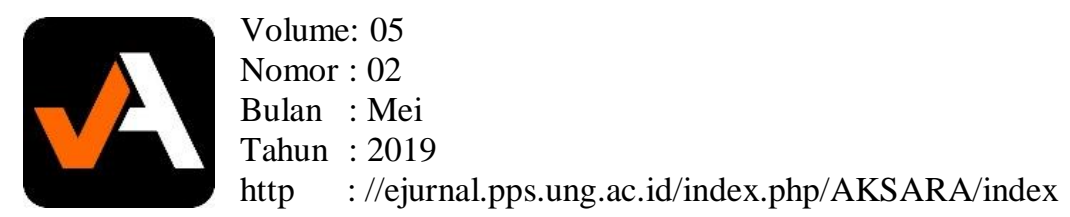

mengatakan bahwa situasi yang terjadi saat ini menunjukan bahwa hanya si miskinlah yang menderita kelaparan; dan pola ketidakadilan dan pengisapan yang berakar dalam yang tumbuh di dalam maupun yang diimpor dari luar- merintangi orang miskin untuk mencukupi kebutuhan panganya.

Islam, sebagai sebuah ajaran menghendaki adanya perhatian pada mereka-mereka dari golongan musthadifin tersebut, karenanya, kerangka terminologi zakat menumbuhkan pemahaman yang di antaranya: pertama, dalam bentuk pengertian tauhid, zakat dilaksanakan berdasarkan petunjuk Allah SWT, sehingga tujuan pokok pelaksanaanya adalah untuk mendekatkan diri kepada tuhan yang maha kuasa, beriman dan ikhlas beramal dalam usaha beribadat kepada tuhan, kedua, dalam pengertian hukum yang berlaku dalam alam beserta isinya agar manusia dapat hidup saling mencintai dan tolong-menolong yang didasari rasa kasih sayang dalam ikatan hukum, di mana keadilan lebih tinggi dari kekuasaan, ia menjadi jiwa hukum dari kebudayaan manusia untuk menciptakan keadilan sosial yang hakiki dalam masyarakat, ketiga, dalam pengertian akhlak, zakat adalah isi dari penjelmaan budi manusia yang mulia, pelaksanaan kehendak rasa si kaya dan si miskin, dan sekaligus sumber praktik persamaan dan persaudaraan kemanusiaan dalam aspek kehidupan sosial, keempat, dalam pengertian sosial, zakat tumbuh untuk mempersamakan dan mempersaudarakan seluruh umat manusia dalam masyarakat kemanusiaan yang satu, yang berwujud pengorbanan benda bagi hidup bertolong-tolongan, kelima, dalam pengertian ekonomi, zakat meninggikan hasrat produksi modern bagi keperluan hidup, melancarkan jalan distribusi dan menstabilitaskan konsumsi dalam kehidupan masyarakat tanpa ada jurang pemisah antara si kaya dan si miskin.

Pelaksanaan zakat telah diwajibkan kepada semua orang muslim karena merupakan bagian dari rukun Islam, kewajiban tersebut berupa pengeluaran berupa sejumlah harta tertentu yang terselip dalam kekayaan yang dimiliki secara riel oleh setiap pribadi muslim yang diwajibkan Allah untuk disedekahkan kepada orang-orang yang berhak setelah mencapai nisab dan haul dengan satu tujuan sosial sebagai satu alternative solusi pengentasan kemiskinan umat, kewajiban tersebut memerlukan satu panduan sehingga mereka yang berkeinginan untuk memberi zakat dapat memahami dengan benar teori dan praksisnya dalam melaksanakan kewajiban tersebut, selain zakat yang menjadi kewajiban untuk mengeluarkanya infak juga merupakan amalan yang sangat dianjurkan oleh Islam, dimana merupakan suatu bentuk perhatian pada mereka yang termasuk dalam musthadifin.

Selain itu, pemanfaatan zakat dan infak yang berasal dari umat islam harus sedini mungkin dikelola dan disalurkan secara efektif sebagai suatu sisi ikhtiar pemberdayaan ekonomi umat, ini karena zakat dan infak merupakan modal dalam upaya peningkatan perekonomian dan kesejahteraan umat, khusus mengenai penyaluran dana zakat dan infak dimana lembaga yang akan menyalurkanya membutuhkan suatu pedoman dalam menerapkanya hal ini disebabkan penyaluran dana zakat dan infak yang berdasarkan pedoman yang ditetapkan atas dasar yang jelas maka penyaluran zakat dan infak dapat mengenai sasaran yang tepat. Jika zakat dan infak disalurkan dengan baik dan bertanggungjawab, maka akan dapat mengatasi atau paling tidak memperkecil masalah kemiskinan. Berdasarkan latar belakang masalah diatas maka penulis mencoba menganalisa implementasi penyaluran dana zakat dan infaq dan yang dilaksanakan oleh Badan Amil Zakat Daerah (BAZDA) Kota Gorontalo, alasan dipilhnya Badan Amil Zakat Daerah (BAZDA) Kota Gorontalo sebagai objek penelitian dikarenakan Badan Amil Zakat Daerah (BAZDA) Kota Gorontalo sebagai lembaga zakat daerah yang terbilang masih muda di daerah Gorontalo akan tetapi BAZDA Kota Gorontalo telah menggunakan sistem manajemen yang baik dan professional dalam mengelola penyaluran dana zakat dan infak, selain itu Badan Amil Zakat Daerah (BAZDA) Kota Gorontalo telah melaksanakan program- 


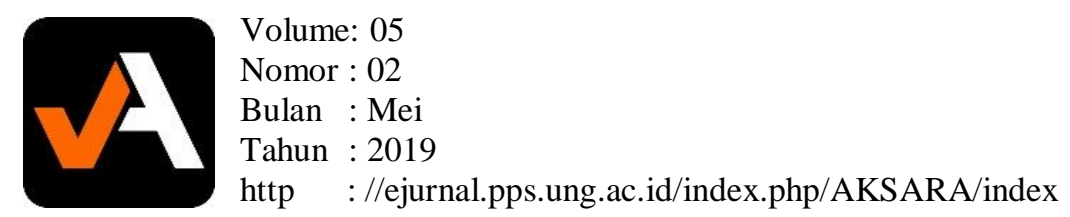

program bantuan pemberdayaan ekonomi masyarakat yang terbukti efektif dalam membantu para golongan musthadifin (para penerima zakat) untuk meningkatkan taraf kehidupannya.

\section{TINJAUAN PUSTAKA}

\section{Pengumpulan dan Pendayagunaan Zakat}

Pemerintah tidak melakukan pengumpulan zakat, melainkan hanya berfungsi sebagai coordinator, motivator, regulator, dan fasilitator, dalam pengelolaan zakat, pengumpulan zakat dilakukan oleh Badan Amil Zakat yang dibentuk oleh pemerintah dan lembaga amil zakat yang dibentuk oleh masyarakat dan dikukuhkan oleh pemerintah, Badan Amil Zakat nasional berkedudukan di ibukota Negara wilayah operasional Badan Amil Zakat adalah pengumpulan zakat pada instansi pemarintah tingkat pusat, swasta nasional, dan perwakilan Republik Indonesia di luar negeri, Badan Amil Zakat di semua tingkatan dapat membentuk Unit Pengumpul Zakat (UPZ), UPZ tidak bertugas untuk menyalurkan dan mendayagunakan zakat, pengumpulan zakat dapat dilakukan melalui penyerahan langsung (datang) ke Badan Amil Zakat, melalui counter zakat, Unit Pengumpul Zakat, pos, bank, pemotongan gaji, dan pembayaran zakat yang dapat mengurangi penghasilan kena pajak, tata cara pengumpulan, pendistribusian, dan pendayagunaan zakat dengan cara menentukan formulir pemungutan/pemotongan yang sebelumnya disiapkan dan disepakati oleh instansi, dalam pengumpulan zakat tersebut Badan Amil Zakat membuka rekening di bank, rekening zakat dipisahkan dari rekening infaq dan sedekah.

Dalam pendayagunaan zakat, ada tiga prinsip yang perlu diperhatikan, yaitu:

a. Diberikan kepada delapan asnaf

b. Manfaat zakat itu dapat diterima dan dirasakan manfaatnya

c. Sesuai dengan keperluan mustahiq (konsumtif dan produktif)

Pendayagunaan zakat yang dikumpulkan oleh Badan Amil Zakat diarahkan para programprogram yang memberi manfaat jangka panjang untuk perbaikan kesejahteraan mustahiq pendayagunaan zakat pada prinsipnya bertujuan untuk meningkatkan status mustahiq menjadi muzakki, melalui peningkatkan kualitas sumber daya manusia dan pemberdayaan sosial serta pengembangan ekonomi.

Program pendayagunaan zakat terdiri dari:

1) Program peningkatkan kualitas sumber daya, meliputi:

Pertama, Beasiswa tunas bangsa

Kedua, Pendidikan alternatif terpadu

Ketiga, Pendidikan keterampilan siap guna.

2) Program pelayanan sosial dan kemanusiaan, meliputi:

Pertama, Program bantuan kemanusiaan

Kedua, Bantuan/ subsidi pelayanan kesehatan

Ketiga, Bantuan /subsidi biaya hidup fakir miskin.

3) Program pengembangan ekonomi umat meliputi:

Pertama, Bina da'wah masjid

Kedua, Bina da'wah kampus/sekolah

Ketiga, Bina da'wah masyarakat.

\section{HASIL PENELITIAN DAN PEMBAHASAN} Temuan Penelitian 


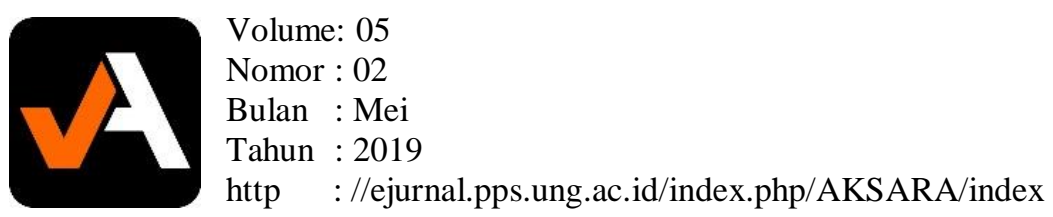

Zakat dan infak sebagai bagian dari ajaran dalam Islam, memberikan suatu landasan bagi pertumbuhan dan berkembangnya kekuatan sosial dan ekonomi dalam kehidupan umat Islam. Penyaluran dana zakat dan infak di Badan Amil Zakat Daerah (BAZDA) Kota Gorontalo dilakukan kepada mereka-mereka yang berhak memperoleh dan mendapatkan haknya (delapan asnaf).

\section{a. Fakir dan Miskin}

Fakir menurut pengertian Badan Amil Zakat Daerah (BAZDA) Kota Gorontalo merupakan orang yang tidak memiliki harta benda dan pekerjaan yang mampu mencukupi kebutuhan sehari-hari dan dia tidak mempunyai suami, ayah, ibu, dan keturunan yang dapat membiayainya baik untuk membeli makanan, pakaian maupun tempat tinggal. Adapun miskin yaitu orang yang memiliki pekerjaan akan tetapi penghasilannya tidak mencukupi kebutuhan hidupnya. Pemahaman ini selaras dengan pendapat mazhab Syafi'i dan mazhab Hambali, dimana menurut kedua mazhab tersebut fakir berasal dari kata al-faqir, yaitu mereka yang tidak memiliki apa-apa (baik itu harta benda, pekerjaan bahkan saudara-saudara terdekat sekalipun) untuk mencukupi kebutuhan hidupnya sehari-hari. Sementara miskin yang merupakan juga diartikan sebagai orang yang memiliki penghasilan akan tetapi penghasilan tersebut belum cukup untuk menopang kebutuhan hidupnya.

Golongan fakir dan miskin merupakan golongan yang paling diutamakan dalam penyaluran dana zakat di Badan Amil Zakat Daerah (BAZDA) Kota Gorontalo, yang mana penyaluran dana zakat dan infak untuk golongan ini telah disalurkan dalam berbagai kegiatan yang dilakukan oleh BAZDA Kota Gorontalo. Golongan fakir dan miskin yang menurut data lebih dari 2.945 orang mendapatkan bantuan kebutuhan pokok (makanan, pakaian, rumah dan bahan pokok lainnya), bantuan modal tanpa bunga kepada 420 orang yang bergerak dibidang usaha kios kecil pada tiap kelurahan, dimana pihak BAZDA membentuk tim yang akan memverifikasi para calon penerima manfaat tersebut. Verifikasi di lakukan dari rumah ke rumah penduduk untuk memastikan kalau calon yang akan dibantu benar-benar fakir miskin yang punya tanggungan dan memiliki kios kecil sebagai penyambung hidup keluarganya, selain itu juga pihak BAZDA Kota Gorontalo memberikan pelatihan kepada fakir dan miskin yang telah diverifikasi untuk mengelola usahanya sehingga pada akhirnya mereka dapat lebih mandiri. Penyaluran zakat dan infak juga disalurkan kepada para tukang cuci yang telah menjadikan profesi sebagai tukang cuci alternatif pekerjaan terakhir. BAZDA Kota Goronalo telah memverifikasi para dhuafa tukang cuci ini dan telah manyantuni sebanyak 515 orang dari hampir 2000 orang tukang cuci yang ada di kota Gorontalo.

\section{b. Amil}

Penyaluran dana zakat yang diprioritaskan setelah fakir miskin di BAZDA Kota Gorontalo adalah amil, yaitu mereka yang melaksanakan segala urusan-urusan yang berkaitan dengan zakat, mulai dari mengumpulkan zakat, mencatat, menghitung dana zakat, dan membagi kannya kepada yang berhak. Data dari Badan Amil Zakat Daerah Kota Gorontalo menunjukkan sebanyak 21 orang yang mendapat dana amil, dimana mereka adalah para karyawan, petugas serta kolektor yang bertugas pada BAZDA Kota Gorontalo. Pada zaman Rasulullah SAW, para amalah-amalah zakat ini dikenal dibagi kepada empat bagian, yaitu hasyarah (orang yang mengumpulkan atau memungut zakat), katabah dan hasabah (orang yang mencatat zakat dan yang menghitung azakat), qasamah (orang yang membagikan atau meyampaikan zakat), kemudian hafadhah (orang yang menjaga dan memelihara harta zakat).

Fungsi serta tugas yang ditanggungjawabkan oleh para amil sangatlah berat dan terikat oleh sebuah bentuk amanah bagi umat, sewajarnyalah tugas ini memiliki resiko serta beban yang berat. Tugas yang diberikan merupakan bagian dari jihad dan pekerjaan yang sangat mulia, 
sehingga prioritas penyaluran dana zakat bagi amil merupakan suatu kepentingan dan berdampak kepada eksistensi pengelolaan dana zakat yang efektif dan efisien karena merupakan bagian dari amanah yang akan diberikan kepada orang yang membutuhkan (mustahiq).

\section{c. Muallaf}

Penyaluran dana zakat di Badan Amil Zakat Daerah (BAZDA) Kota Gorontalo juga diberikan kepada para muallaf, yaitu mereka yang telah masuk Islam dan sebelumnya adalah non-muslim. Pemberian zakat kepada muallaf ini bertujuan untuk memberikan pertolongan ataupun menarik simpati mereka terhadap Islam, sekaligus memantapkan hatinya (keyakinan) terhadap agama Islam, agar mereka tidak berbuat jahat terhadap Islam bahkan rela membela orang Islam. Ibnu Abbas membagi golongan ini kepada empat kelompok, yaitu muallaf yang masih lemah imannya, pemuka-pemuka yang memiliki kerabat yang sebanding tetapi masih kafir, orang Islam yang berkediaman diperbatasan dan membela negeri dari serangan musuh, serta orang yang diperlukan untuk menarik zakat dari mereka yang tidak mau mengeluarkan zakat.

Orang kafir yang ada harapan masuk Islam dan orang yang baru masuk Islam yang imannya masih lemah adalah merupakan golongan yang rawan, artinya keteguhan dan keyakinan akan agama Islam masih lemah, sehingga diberikan kepadanya hak atau bagian dari zakat yang berfungsi sebagai wujud pertolongan dan kesediaannya untuk membela agama Islam. Akan tetapi golongan ini tidak boleh dipandang sebelah mata, karena bagaimanapun juga golongan ini merupakan contoh bagi non-muslim lainnya jika mereka akan memeluk agama Islam. BAZDA Kota Gorontalo telah menyerahkan santunan kepada 593 orang muallaf yang tersebar pada 49 kelurahan di Kota Gorontalo

\section{d. Gharimin}

Konsep gharimin menurut Badan Amil Zakat Daerah (BAZDA) Kota Gorontalo adalah mereka-mereka yang mempunyai tanggungjawab hutang kepada orang lain, dan tidak sanggup untuk melunasi hutang tersebut. Menurut Ash Shiddieqy, gharimin mengandung arti sebagai orang yang mempunyai hutang dan tidak mampu membayarnya, termasuk berhutang untuk kemashlahatannya sendiri, kemashlahatan bersama, atau demi kemashlahatan umum, seperti membangun mesjid, membuat jembatan untuk kepentingan umum, dan lainnya.

Prioritas dana zakat bagi gharimin ini sangat sesuai dan penting, tetapi perlu dilakukan evaluasi terhadap mereka yang berhak menerima dana zakat tersebut. Karena secara empiris, banyak orang yang berhutang untuk kepentingannya sendiri akan tetapi merugikan orang lain, bahkan mengancam kehidupan orang banyak, seperti penguasa ataupun konglomerat yang berhutang akan tetapi tidak memikirkan nasib rakyat jelata. Pengelola dana zakat harus benarbenar jeli terhadap gharimin yang berhak menerima zakat dan perlu dibantu untuk melunasi hutangnya, karena hutang ini merupakan beban dan tanggungjawab masing-masing individu kelak di akhirat.

\section{e. Fisabilillah}

Asnaf fisabilillah adalah salah satu yang mendapat perhatian serius dari BAZDA Kota Gorontalo. Ini ditandai dengan menyerahkan beasiswa bagi pelajar dan mahasiswa yang kurang mampu sebanyak 100 orang, diantaranya BAZDA Kota Gorontalo telah menyalurkan beasiswa kepada para pelajar dan mahasiswa berprestasi. BAZDA Kota Gorontalo telah menyalurkan beasiswa kepada sebanyak 87 orang siswa Madrasah melalui Kementrian Agama Kota Gorontalo, dimana Madrasah Ibtidaiyah Terpadu (MIT) Ma'rifah adalah sekolah formal swasta yang seratus persen mengratiskan biaya pendidikan pada seluruh siswa, (sumber dana diambil 


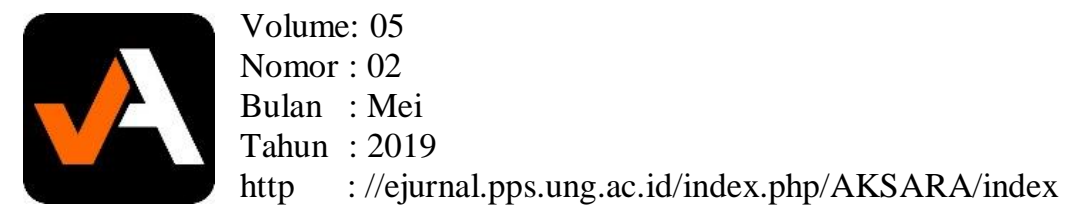

dari zakat dan infaq yang masuk setiap bulan bagian dari ashnaf fisabilillah). Ini dilakukan karena Madrasah Ma'rifah dibangun untuk mendidik anak-anak dari keluarga yang kurang mampu secara ekonomi. Selain itu BAZDA Kota Gorontalo melakukan pembentukan organisasi Pemuda dan Remaja Pecinta Masjid yang disingkat PR TAJID FISABILILLAH. “ PR TAJID hadir karena keprihatinan terhadap kondisi pemuda dan remaja Islam saat ini yang mulai jauh dari masjid. Masjid bukan hanya tempat ibadah, melainkan sebagai pusat perjuangan, sebagaimana dicontohkan oleh Rasulullah SAW dan para sahabat, untuk itu BAZDA Kota Gorontalo melalui wadah PR. TAJID, fisabilillah, melakukan pelatihan da'i muda untuk diterjunkan ke tengah-tengah masyarakat yang saat ini terasa kekurangan da'i selain daripada itu pembentukan PR. TAJID memberikan dampak pengaruh kepada pemuda dan remaja yang mulai jauh dari masjid termotivasi untuk memakmurkan masjid serta mempelopori kegiatan keagamaan disetiap Kelurahan di Kota Gorontalo. Adapun bentuk perhatian terhadap organisasi Pemuda dan Remaja Pecinta Masjid, BAZDA Kota Gorontalo dengan dukungan Pemerintah Gorontalo telah mengasuransikan seluruh pengurus PR. TAJID Kota Gorontalo sebanyak 1339 orang melalui program Jamkesman (Jaminan Kesehatan Mandiri).

\section{f. Ibnu Sabil atau Musafir}

Badan Amil Zakat Daerah Kota Gorontalo juga menyalurkan dana zakat kepada ibnu sabil atau musafir, yaitu mereka yang sedang melintas dari suatu daerah ke daerah lain, ataupun orang-orang yang sedang melakukan perjalanan sangat jauh. Penyaluran dana zakat bagi golongan ini menurut data dari BAZDA Kota Gorontalo telah diberikan kepada 3 (tiga) orang musafir yang pernah berkunjung di daerah Gorontalo diantaranya seorang juru dakwah yang kehabisan bekal dalam perjalanan. Dalam Islam, ibnu sabil juga dimaknakan sebagai mereka yang kehabisan belanja (bekal) dalam perjalanannya. Mereka juga orang yang sedang dalam perjalanan yang bukan maksiat, kemudian mengalami kesengsaraan dalam perjalanannya.

Zakat yang diberikan merupakan bentuk dari kepedulian dan jaminan sosial kemasyarakatan, seperti halnya di zaman Umar bin Khattab ra, didirikan rumah khusus untuk membantu para musafir yang kehabisan bekal, sehingga dengan adanya rumah sebagai tempat persinggahan musafir sangat membantu para ibnu sabil yang sedang kehabisan bekal dalam perjalanan.

\section{g. Operasional dan Inventaris}

Penyaluran dana zakat di BMT BAZDA Kota Gorontalo untuk kepentingan operasional dan inventaris juga diberikan sebagai wujud perhatian terhadap kegiatan administrasi. Dana zakat ini digunakan untuk keperluan transportasi, operasional zakat, pembelian computer, alat tulis-menulis, observer (pembantu), upah dan konsumsi karyawan, dimana dana ini juga merupakan bagian dari dana yang diperuntukkan bagi amil dan fisabilillah.

Perlu diketahui, bahwasannya harta zakat dialokasikan kepada delapan asnaf di atas, walaupun operasional dan inventaris merupakan bagian dari kegiatan yang dilakukan oleh amil, maka bukan berarti ini adalah bagian dari golongan (asnaf), melainkan operasional dan inventaris hanya sebagai bagian dari alur kerja dalam proses pendayagunaan zakat di BAZDA Kota Gorontalo.

\section{Pembahasan}

Pemetaan konsep delapan asnaf ini jika diaktualisasikan, akan memberikan kepada kita suatu tolak ukur yang aktual dalam pemetaan sasaran pemanfaatan dalam penyaluran dana zakat dan infak di lapangan. Konsep delapan asnaf ini muncul sebagai bentuk untuk 
melepaskan masyarakat dari kemelaratan (kemiskinan), misalnya kebanyakan dari masyarakat kita tidak mampu mendidik atau menyekolahkan anaknya, sehingga sulit bagi anak-anaknya untuk lepas dari kemiskinan karena pendidikan yang diperoleh di sekolah sudah menjadi suatu alat melepaskan diri dari pengangguran. Apalagi program pendayagunaan zakat dan infak ini dilakukan untuk meningkatkan kualitas sumberdaya, pelayanan sosial dan kemanusiaan, serta pengembangan ekonomi.

Konsep-konsep ini menjadi acuan bagi sebagai lembaga yang mengembangkan manajemen zakat dan infak secara profesional untuk mengumpulkan informasi dan menyusun rencana ataupun konsep yang bisa digunakan sebagai tolak ukur operasionalnya sesuai dengan realitas dan kebutuhan masyarakat. Penyusunan dan pengumpulan informasi ini dilakukan oleh Badan Amil Zakat Daerah (BAZDA) Kota Gorontalo sebagai bagian dari lembaga pengelola zakat dan infak untuk menentukan pemetaan sosial dalam penyelenggaraan kegiatan penyaluran dan pemanfaatan dana zakat dan infak, dengan demikian kemiskinan dan kemelaratan atau kedhaifan yang melekat pada masyarakat dalam berbagai bentuk dapat diketahui dengan jelas dan fungsi pemanfaatan zakat dan infak sebagai fungsi sosial dalam masyarakat betul-betul mencapai sasaran yang diinginkan, dan BAZDA Kota Gorontalo dapat membantu masyarakat mengatasi persoalan sosial ekonominya.

Badan Amil Zakat Daerah (BAZDA) Kota Gorontalo sebagai lembaga sosial yang memiliki fungsi sebagai lembaga pengelola dana sosial zakat dan infak dimana usaha pokoknya adalah menerima dan menyalurkan dana ummat Islam yang bersifat non komersial (sosial) yang mana dana tersebut bersumber dari zakat dan infak. Adapun implementasi dari penyaluran dana zakat dan infak yang dilakukan oleh BAZDA Kota Gorontalo memiliki visi terhadap pengentasan kemiskinan, meringankan beban ekonomi, membantu fakir miskin dan yatim piatu, serta mengedepankan dan memajukan moralitas umat Islam dalam bidang pendidikan.

Mengemban fungsinya sebagai unit sosial penataan organisasi dan manajemen dalam upaya optimalisasi pengelolaan zakat, BAZDA Kota Gorontalo telah melakukan upaya-upaya dalam mengumpulkan informasi terhadap pemetaan struktur sosial dan ekonomi masyarakat di Gorontalo, dengan berbagai media dan penyuluhan baik melalui media massa, visual maupun non visual. Hal ini merupakan suatu usaha dalam pengembangan manajemen zakat, serta pembinaan kelembagaan zakat yang mencakup administrasi, organisasi dan tradisi dalam manajemen zakat.

Sebagai lembaga keuangan yang telah memiliki potensi yang sangat baik dalam meningkatkan kemampuan dan kapasitasnya sebagai lembga pemberdayaan zakat (pengumpulan dan pendayagunaan zakat) dan telah berperan nyata di masyarakat. BAZDA Kota Gorontalo telah menyesuaikan diri terhadap informasi, administrasi, organisasi dan tradisi yang kesemuanya merupakan pilar-pilar utama bagi terwujudnya lembaga-lembaga sosial kemasyarakatan yang mampu menjalankan fungsinya dengan baik dalam masyarakat, dimana fungsi-fungsi manajemen meliputi fungsi penerimaan pengumpulan, penyaluran dan pendayagunaan zakat, fungsi pembinaan kesejahteraan masyarakat, dan fungsi pengembangan swadaya masyarakat.

Dengan demikian, BAZDA Kota Gorontalo sebagai icon dalam pengembangan manajemen zakat dan lembaga yang masih relatif baru dapat memberikan langkah-langkah dalam pengembangan berbagai kelembagaan zakat khususnya bagi lembaga amil zakat di daerah lain. Di samping itu dengan berkumpulnya sumber daya manusia yang dapat memikirkan pengembangan kelembagaan zakat dalam badan amil zakat daerah dapat menjadi modal dasar dan cikal bakal dalam pengembangan manajemen zakat secara profesional. 


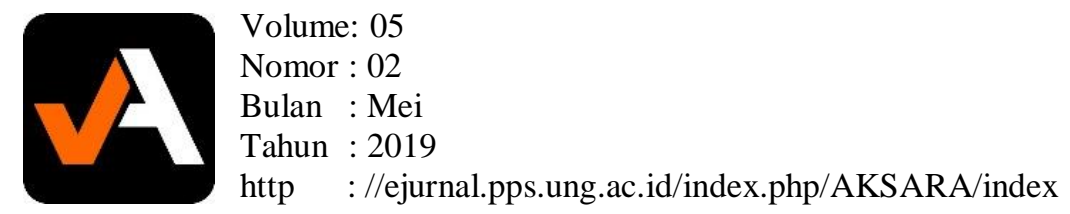

Tidak dapat dipungkiri lagi, bahwasannya keberadaan maupun eksistensi lembaga ini menjadi contoh bagi lembaga zakat yang lain dalam pengembangan manajemen dan organisasi zakat. Bahkan lembaga ini menjadi icon di daerah Gorontalo, sehingga perlu kiranya lembaga BAZDA Kota Gorontalo untuk memajukan dan mengadakan evaluasi dalam manajemen pengelolaan dana zakat dan infak agar penyaluran dana zakat dan infak benar-benar telah sampai kepada masyarakat yang benar-benar membutuhkan.

\section{PENUTUP}

Berdasarkan dari hasil analisis dan pembahasan dalam penelitian ini, maka dapat ditarik kesimpulan sebagai berikut: Impementasi penyaluran dana zakat dan infak di Badan Amil Zakat Daerah Kota Gorontalo sesuai dengan pedoman pengelolaan zakat Departemen Agama Republik Indonesia Tahun 2004, dimana dalam pendayagunaan zakat secara prinsip dana tersebut diberikan kepada delapan asnaf, manfaat zakat dan infak dapat diterima dan dirasakan manfaatnya serta sesuai dengan keperluan mustahiq (konsumtif dan produktif), dan pendayagunaan zakat tersebut ditujukan untuk program jangka panjang untuk perbaikan kesejahteraan dan meningkatkan status mustahiq menjadi muzakki, melalui peningkatan kualitas sumber daya manusia (beasiswa, pendidikan terpadu, pendidikan keterampilan), pemberdayaan sosial dan kemanusiaan (bantuan kemanusiaan, pelayanan kesehatan, biaya hidup fakir miskin), serta pengembangan ekonomi ummat (bina dakwah mesjid, kampus/sekolah dan masyarakat).

\section{DAFTAR PUSTAKA}

Depertemen Agama Kantor Wilayah Propinsi Gorontalo, Pedoman Pengelolaan Zakat, 2004 Hafidhuddin Didin, Tentang Zakat, Infak dan Sedekah, Gema Insani, Jakarta, 2004

Hasan Muhammad Iqbal, Pokok-Pokok Metodologi Penelitian dan Aplikasinya, Ghalia Indonesia, Jakarta, 2002

Jogiyanto, Metode Penelitian Bisnis: Salah Kaprah dan Pengalaman-Pengalaman, BPFE UGM, Yogyakarta, 2005

Ikatan Akuntan Indonesia, Pernyataan Standar Akuntansi Keuangan no.59 (Akuntansi Perbankan Syariah), Salemba Empat, Jakarta, 2002

Inoed Amiruddin, Anatomi Fiqih Zakat, Badan Amil Zakat dan Pustaka Pelajar, Sumatera Selatan, 2005

Teungku Muhammad Hasbi Ash Shiddiegy, Pedoman Zakat, PT Pustaka Rizki Putra, Semarang, 1999

Qardawi Yusuf, Hukum Zakat, PT Pustaka Litera Anatar Nusa, Jakarta, 2004

Daud Ali Muhammad, Sistem Ekonomi Islam, Zakat dan Wakaf, UI - Press, Jakarta, 1988 